Article

\title{
On the Connection between Atmospheric Moisture Transport and Dry Conditions in Rainfall Climatological Zones of the Niger River Basin
}

\author{
Rogert Sorí *, Raquel Nieto ${ }^{\circledR}$, Anita Drumond ${ }^{\circledR}$, Milica Stojanovic and Luis Gimeno \\ Environmental Physics Laboratory (EPhysLab), Facultad de Ciencias, Universidade de Vigo, 32004 Ourense, \\ Spain; rnieto@uvigo.es (R.N.); anitadru@uvigo.es (A.D.); mstojanovic@uvigo.es (M.S.); 1.gimeno@uvigo.es (L.G.) \\ * Correspondence: rogert.sori@uvigo.es; Tel.: +34-988-387-208
}

Received: 20 February 2019; Accepted: 21 March 2019; Published: 26 March 2019

check for updates

\begin{abstract}
The hydroclimatology of the Niger River basin, located in West Africa, is very complex. It has been widely studied because of its importance to the socioeconomic activities of the countries that share its natural resources. In this study, to better understand the causes and mechanisms that modulate the rainfall over the Niger River basin, we identified the most relevant moisture sources for precipitation within the basin. The Lagrangian model FLEXPART was utilised to track backward trajectories of air parcels initially losing humidity over climatological rainfall zones of the basin. Along 10-day backward trajectories, we computed the budget of the difference between evaporation and precipitation $(E-P)$ from 1000 to $0.1 \mathrm{hPa}$, permitting the identification of those regions where moisture uptake $((E-P)>0)$ prevail. The study was conducted for the period 1980-2017. Monthly maps of $((E-P)>0$ were developed to illustrate the regions from where moisture is transported, contributing to precipitation in the Niger River basin. The spatial variability of the sources matches the precipitation variability over the basin restricted to surrounding areas of the Niger River basin during months with low average precipitation and widely spreading over the continent and the Atlantic Ocean in months with high average precipitation. During climatological dry months (e.g., December, January and February) the continental sources of West and Northeast Africa and the climatological rainfall zones themselves provide most of the moisture for precipitation. However, during the rainy season, the moisture supplies from oceanic sources increase, becoming greater than the contribution from land-based sources during August (the rainiest month). Dry conditions were identified for each climatological rainfall zone using the Standardised Precipitation Index. Similar to many previous studies, we found that the 1980s were highlighted by dry conditions. Local recycling and particularly moisture uptake from the tropical South Atlantic Ocean seem to be highly related to dry and wet conditions in the basin. A reduction on the moisture uptake from surrounding continental sources and the tropical South Atlantic Ocean is almost persistent during extremely dry conditions. Ascending movements are restricted to the lower troposphere during extremely dry conditions and oscillate latitudinally as well as precipitation.
\end{abstract}

Keywords: moisture sources; moisture uptake; dry conditions; climatological rainfall zones; Niger River Basin

\section{Introduction}

Hydro-climatic changes in the Niger River basin (NRB) have had significant impacts on the local population since the 1970s [1]. It is well known that there are strong spatial as well as intra- and inter-annual variabilities in Sahel rainfall [2-4]. The Sahelian precipitation $(P)$ alterations are primarily a consequence of contrasting circulation, together with recycling of local evaporation and moisture 
advected from the tropical North Atlantic Ocean and the Gulf of Guinea [5-7], which favours the West African Monsoon (WAM) development during the rainy season. The determining factors are the positional shifts in the African Easterly Jet and West African Westerly Jet (AEJ and WAWJ, respectively), the African easterly waves and the Intertropical Convergence Zone (ITCZ) $[6,8,9]$. For West Africa (WA) and the NRB, dry season approximately occurs from November to April and rainy season from May to October $[10,11]$. Observed changes in the onset and demise of seasonal rains over WA and the Sahel region during the last few decades have been documented and are a discernible indication of climate change [12-14]. The sea surface temperature (SST) variability in the Gulf of Guinea and its implications for spatiotemporal variability of the precipitation in WA-particularly during the WAM in the course of the rainy season - have been well documented (e.g., Odekunle and Eludoyin [15]; Joly and Moldoire [16]; Ali et al. [17]; Nnamchi et al. [18]). However, to investigate the rainfall variability over a region one should also consider that within a catchment area, precipitation originates from one of three sources: the moisture already present in the atmosphere, the convergence of the moisture advected into the region by winds or the evaporation of surface moisture into the atmosphere within the catchment itself [19].

Applying a recycling model based on mass balance, Gong and Eltahir [20] found that evaporation in the tropical Atlantic Ocean, WA and Central Africa contributed approximately 23, 27 and 17\% of rainfall, respectively, in WA. This means that recycling plays a key role in local precipitation amounts $[5,21]$ and, indeed, WA is considered among the major sinks for continentally evaporated water [22]. However, other findings argue that local evaporation in WA is not the governing factor controlling local precipitation in this region [23,24]. Most recently, Sorí et al. [11] utilised a Lagrangian method to identify the main sources of moisture for the NRB during the dry and rainy seasons and computed moisture uptake. Similar to previous findings, these authors found that the eastern South Atlantic Ocean comprising the Gulf of Guinea is the most important oceanic moisture source for the NRB, while the Sahel region and the NRB itself are the most important among the continental sources. An overview of the principal moisture sources for the NRB was calculated utilising a quasi-isentropic back-trajectory scheme [25] and is available at http://cola.gmu.edu/wcr/river/ basins.html. Identification of moisture sources has become an important research tool in the study of extreme events (e.g., floods [26,27] and droughts [28,29]) and for regional and global climatic assessments [30]. Considering the high seasonal variability of the $P$ in the NRB, the first objective of this study was to identify the most important moisture sources for $P$ in monthly climatological rainfall zones (CRZs) within the NRB. This approach led to accurate results in comparison to previous studies that considered the whole NRB [11,25] and the Sahel [21].

A primary impact of below average rainfall is the occurrence of dry conditions. Sustained over weeks and months and over local or regionally extensive regions, it typically results in agricultural, hydrological, and/or societal droughts [31]. During the second half of 1900-2013 (1957-2013), African droughts have intensified in terms of their frequency, severity and geospatial coverage [32], threatening the food supply of millions of people. Particularly, the semi-arid West African Sahel has been subject to nearly three decades of abnormally dry conditions, starting with the drought period of 1968-1973 [33] and with the most intense droughts occurring during the early 1980s [4,34]. However, rainfall recovery over the Sahel after 1990 has been documented [4,33,35], although it is more pronounced in the eastern Sahel [4]. Considering that approximately 100 million people live in countries sharing the NRB and it plays a crucial role in the economic and social development of the region, a better understanding of the mechanisms leading to dry conditions in WA is necessary in the current and future context of socioeconomic and environmental changes [36]. Therefore, the second aim of this study was to identify dry conditions in the CRZs and assess the role of sources during extremely dry conditions. This approach has been proven by previous studies to provide new insights into the hydrological cycle in regions such as Amazonia [37], the Congo River basin [29], North America, [28] and Europe [38-40]. 


\section{Study Region}

The NRB is in WA (Figure 1) and covers $7.5 \%$ of the continent spreading over 10 countries. The basin drains to the Niger River (NR), approximately $4100 \mathrm{~km}$ in length and the third-longest river in Africa after the Nile and the Congo/Zaire rivers [41]. From the perspective of water resources, the NRB can be divided into four zones with relatively homogenous physical and geographical characteristics; the Upper Niger Basin, the Inland Delta entirely situated in Mali, the Middle Niger Basin and the Lower Niger Basin [42]. For the approximately 100 million inhabitants, the NRB is a source of identity, a route for migration, commerce and conflict [43]. Approximately $65 \%$ of the active WA and Sahelian inhabitants (more than one-half of which are women) work in the agricultural sector and are therefore vulnerable to climatic hazards and environmental factors. In fact, their vulnerability is increased because the NRB climate is very complex, with different climatic types, predominantly hot and dry according to the Köppen-Geiger classification [44] (Figure 1). Hence, the majority of agricultural production in the sub-region is dominated by subsistence farming nearly exclusively based on rainfed agriculture and extensive animal husbandry systems [45].

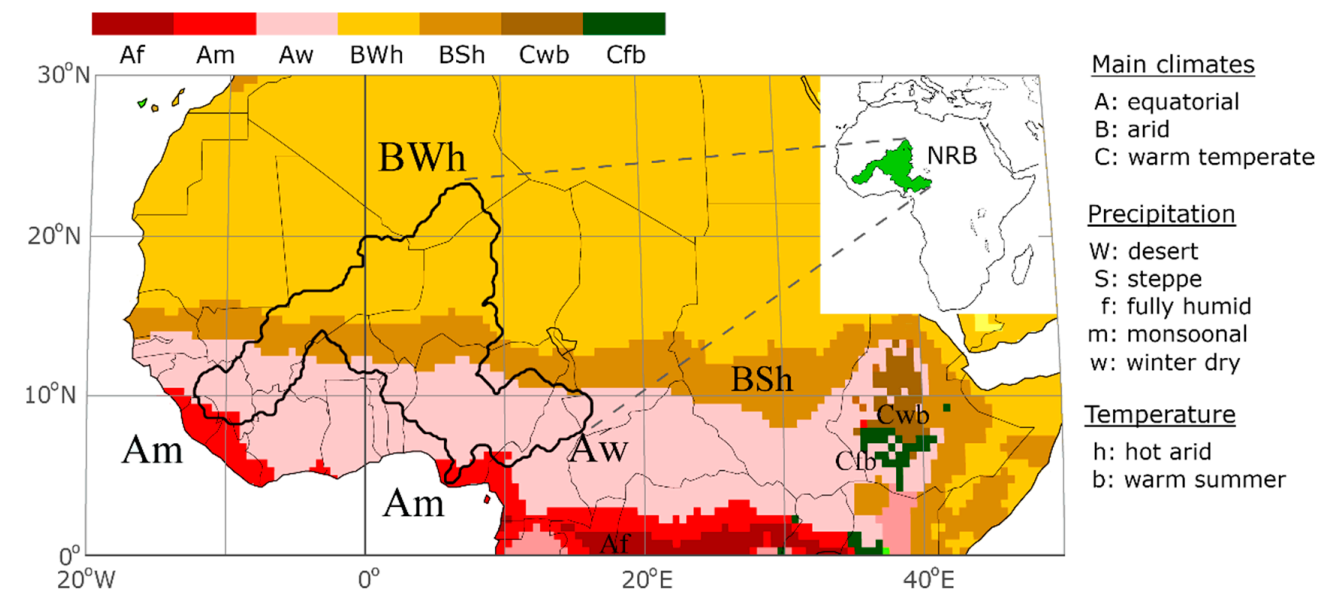

Figure 1. Niger River Basin (NRB) location and main climatic types in northern Africa according to the Köppen-Geiger climate classification.

\section{Materials and Methods}

\subsection{Methods}

\subsubsection{Identification of Climatological Rainfall Zones (CRZs)}

Due to contrasting climatic types within the NRB (Figure 1), we performed a frequency analysis of monthly $P \geq 0.1 \mathrm{~mm} /$ day. This threshold is normally used to denote a "rain day", a day during which a station has recorded $0.1 \mathrm{~mm}$ or more of rainfall [46-48]. However, we utilised this threshold at a monthly scale for bounding climatological rainfall zones (CRZs), those that on average receive rainfall within the NRB.

\subsubsection{Identification of Monthly Climatological Moisture Sources}

Global outputs from a modelling experiment using the Lagrangian Particle dispersion model (FLEXPART) v9.0 [49,50] were utilised to investigate the origin of atmospheric moisture that contributes to precipitation over the NRB during the period 1980-2017. Initially, the model considers the atmosphere homogeneously divided into approximately 2 million "particles" (or "parcels") evenly distributed over the entire globe and permits one to track them backward and/or forward in time. Along the trajectories the rate of moisture increases (through evaporation from the environment, $e$ ) or decreases (through precipitation, $p$ ) is calculated by changes in the specific humidity $(q)$ over time $(t)$ using Equation (1), assuming that particle mass $(m)$ is constant. The backward mode 
is computationally advantageous if the number of receptors is less than the number of sources considered [51]. The advection of air parcels mainly consists of a "zero acceleration" scheme that solves the trajectory equation. For the moisture diagnostic, we used 6-hourly steps for recalculating the $(e-p)$ budget for the respective air parcel. For the backward experiment implemented in this study, we considered the average residence time of the water vapour in the atmosphere to be 10 days [52].

$$
(e-p)=m\left[\frac{d q}{d t}\right]
$$

By integrating the $(e-p)$ values for all parcels in a vertical column over an area " $A$ ", we obtained the surface freshwater flux $((E-P))$ using Equation (2) as follows:

$$
E-P \approx \frac{\sum_{k=1}^{k}(e-p)}{A}
$$

where $E$ represents the evaporation and $P$ the precipitation per unit area. To identify the moisture sources relevant for the $P$ over each CRZ, we considered the backward trajectories of air parcels that initially lose moisture $(d q / d t<0)$ over these regions. The remaining trajectories were not undertaken for assessment. In those regions along the trajectories where $(E-P)>0$, moisture gain occurs and these regions are considered as moisture sources. In contrast, where air parcels lose humidity $((E-P)<0)$ the regions are considered as moisture sinks. In this study, only positive values of $(E-P)$ are assessed. To set the limits of the most important moisture sources we considered the threshold of $(E-P)=0.1 \mathrm{~mm} /$ day, allowing us to quantify the moisture uptake from each source during the study period. The criteria for delimiting the most important moisture sources is controversial in several studies. However, the threshold utilised here accords with that assumed by Nieto et al. (2014) to propose a catalogue of moisture sources for continental climatic regions and is quite similar to that utilised by Sorí et al. [11] for identifying the most important seasonal moisture sources of the NRB. The sources were separated into continental and oceanic to separately quantify the moisture uptake and later compare the values among different locations.

There are several methods to investigate the origin of moisture (e.g., Eulerian, Lagrangian and Physical Water Vapour Tracers (isotopes)) [53]. However, the Lagrangian diagnostic scheme has proved to be a powerful tool to identify moisture sources and investigate anomalous atmospheric moisture transports during hydroclimatic extremes $[40,54,55]$ in several river basins but most extensively in the Amazon River basin [56], Yangtze River basin [57], La Plata River basin [58], Danube River basin [59] and as previously stated the NRB [11]. The model enables establishment of the moisture source-receptor relationship along suitably defined trajectory ensembles. An important concern in Lagrangian methods is the trajectory accuracy, which largely depends on the temporal and spatial accuracy of the wind fields and calculation schemes. In addition, the overall $(E-P)$ diagnosis will also depend on the accuracy of input datasets representing the water balance. FLEXPART v9.0 utilises parametrisations of turbulent motions and convection which are particularly important to simulate the effects of moisture (i.e., clouds). Nevertheless, along with individual trajectories, $q$ fluctuations can occur for nonphysical reasons (e.g., because of $q$ interpolation or trajectory errors), a limitation that is partially compensated for by the presence of several particles in an atmospheric column over the target area [49].

\subsubsection{Identification of Dry and Wet Conditions}

Various drought indices have been developed and used by meteorologists and climatologists throughout the world [60]. Many are based on traditional methods for drought assessment, such as those derived from precipitation and evaporation time series [61,62]. Previous results reflect that the Standardised Precipitation Index (SPI) is robust and sensitive to dryness in the NRB compared to other indices [63]. In this study, the SPI [63] at a temporal scale of 1 month (hereafter SPI1) was used to 
identify dry and wet conditions in the CRZs of the NRB. In arid climatic regimes is recommend caution when applying short-time-scale SPI because numerous dry events ( 0.00 rainfall even in non-arid climates) will make the SPI behave erratically [64]. For this reason, is used the temporal scale of one month (SPI1). The computation of the SPI1 for the CRZs avoids considering warm and dry arid zones, which are typically excluded because of several methodological limitations [64-66]. The SPI uses historical precipitation records for a location, that is summed over $n$ months and normalised to the standard normal distribution $(\mu=0, \sigma=1)$ by fitting a parametric statistical distribution to the time of year during a reference period $[63,67]$. The Gamma parametric statistical distribution was utilised. An advantage of the SPI is that it allows comparisons among locations of different climatic zones and highly non-normal precipitation distributions. We focused on extremely dry conditions according to the classification system proposed by Agnew [68] (Table 1) to assess the role of the sources. This classification is based on the probability classes rather than the magnitudes of the SPI and is therefore suggested as a more rational approach. The value of -1.65 identifies those months in which extremely dry conditions would return with a probability of $5 \%$, that is, once every 20 years. The standardised Surface Soil Moisture Anomalies (SSMA) were calculated and correlated with the SPI1 to assess the primary impact of the rainfall deficit/excess on the surface.

Table 1. SPI classification according to Agnew [68].

\begin{tabular}{ccc}
\hline SPI & Probability & Category \\
\hline$>1.65$ & 0.05 & Extremely humid \\
$>1.28$ & 0.1 & Severely humid \\
$>0.84$ & 0.2 & Moderately humid \\
$>-0.84$ and $<0.84$ & 0.6 & Normal \\
$<-0.84$ & 0.2 & Moderately dry \\
$<-1.28$ & 0.1 & Severely dry \\
$<-1.65$ & 0.05 & Extremely dry \\
\hline
\end{tabular}

\subsection{Data}

FLEXPART v9.0 requires two-dimensional fields such as those for the surface pressure, total cloud cover, 10-m horizontal wind components, 2-m temperature and dew point temperature, large-scale and convective precipitation, sensible heat flux, east/west and north/south surface stress, topography, Land sea-mask and the sub-grid standard deviation of topography. The analyses were carried out for a 38-year period (1980-2017) utilising ERA-Interim reanalysis [69] datasets every $6 \mathrm{~h}$ at a resolution of $1^{\circ}$ in longitude and latitude on 60 vertical levels from 1000 to $0.1 \mathrm{hPa}[49,50]$. Compared to other reanalysis such as the Modern-Era Retrospective analysis for Research and Applications (MERRA) [70] or Climate Forecast System Reanalysis (CFRS) [71], the ERA-Interim has a reasonable closure of the terrestrial and atmospheric water balance and good agreement with the observational datasets [72], fitting very well with the purpose of this study. We expect that future studies utilising the ERA5 [73] reanalysis datasets should reduce the uncertainties due to major resolution and improved data assimilation.

Monthly average $P$ series over the CRZs was utilised to calculate the SPI1. $P$ and Potential Evapotranspiration $(P E T)$ data at a resolution of $0.5^{\circ} \times 0.5^{\circ}$ belonging to the Climatic Research Unit (CRU TS v.4.01) [74] and the Surface Soil Moisture data at a resolution of $0.25^{\circ} \times 0.25^{\circ}$ are from the Global Land Evaporation Amsterdam Model (GLEAM v3.2a) [75,76]. In addition, Omega (Vertical Velocity) data at a resolution of $2.5^{\circ} \times 2.5^{\circ}$ are from the National Centres for Environmental Prediction (NCEP) National Centre for Atmospheric Research (NCAR) Reanalysis [77].

\section{Results and Discussion}

\subsection{Rainfall over the NRB}

The monthly frequency of an average $P \geq 0.1 \mathrm{~mm} /$ day over the NRB is shown in Figure 2. Rainfall is climatologically restricted to the southern part of the basin from November to January 
but typically occurs over nearly the whole basin from May to September. March, April and October appear to be transitional months. This indicates that rainfall is not typical in the central and northern NRB particularly during the boreal winter months of November, December, January and February, in accordance with the main climatic types shown in Figure 1. According to Lienou et al. [42] the $P$ intensity is relatively homogenous on the east-west axis but develops a serious gradient on the north-south axis following the scale of the basin. This is also a problematic for modelling studies, Siegmund el al. [78] showed that monthly precipitation forecast of the Climate Forecast System version 2 (CFSv2) revealed strong deficits regarding the northward progression of the rain belt over WA; and despite most forecast systems utilised by Rodrigues et al. [79] capture the main features associated with the Guinean regime (rainfall located south of $10^{\circ} \mathrm{N}$ ) and the seasonal northward migration of rainfall, they are all biased and several of the forecast systems simulate the rainfall anomalies in the wrong location. The latitudinal variability of rainfall over the basin is evident by the monthly frequency shifts shown in Figure 2, identifying CRZs (enclosing from 1 up to 38 frequencies) within the NRB for each month. The variable extension of the CRZ throughout the year is in agreement with the average $P$, as shown in Figure 3. During December-January-February the minimum $P$ values occur, while the rainiest months are July-August-September. The peak of August is associated with the peak of the WAM [4], after which $P$ decreases (as shown in Figure 3) and the size of the CRZs also decreases (as shown in Figure 3). Considering previous results for WA and the whole NRB, the mean annual cycle of precipitation is characterised by the same evolution as that shown in Figure 3; the minimum values at the beginning of the year increase monthly, reaching a maximum during August [10,11].

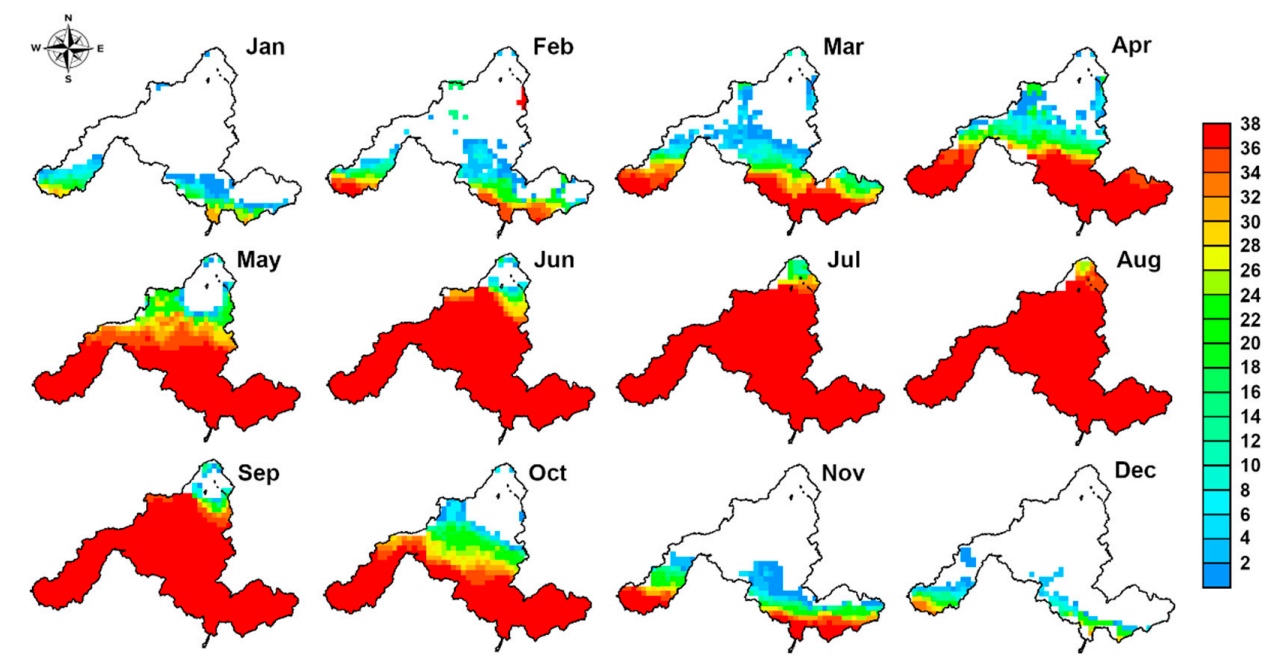

Figure 2. Monthly frequency of $P \geq 0.1 \mathrm{~mm}$ /day over the NRB during 1980-2017. The climatological rainfall zone (CRZ) of each month is shaped by integrating all frequency patterns.

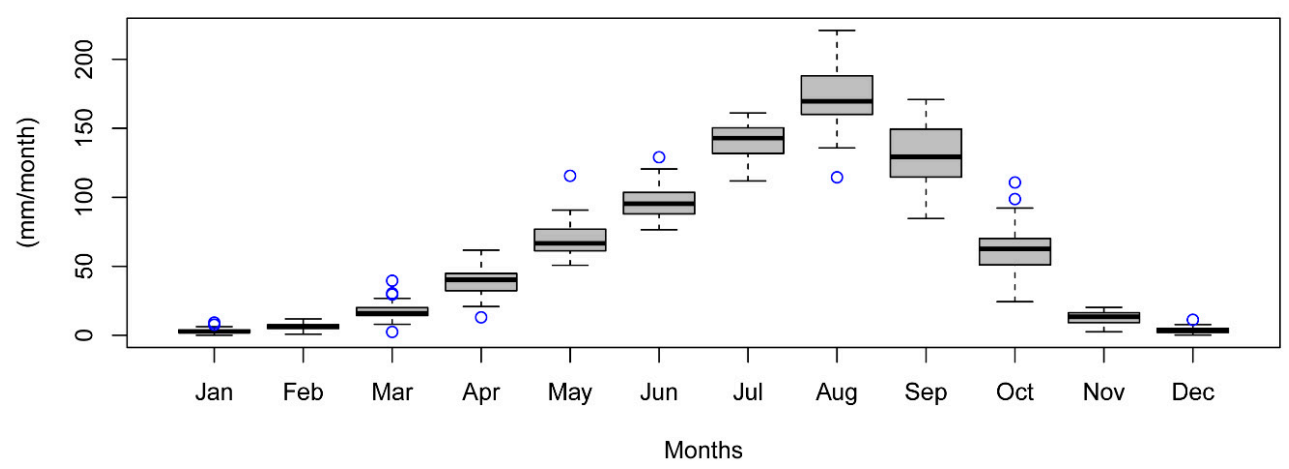

Figure 3. Histogram of $P$ for each CRZ shown in Figure 2. 


\subsection{Identification of Moisture Sources}

Those air parcels losing humidity $((E-P)<0)$ over each CRZ were tracked backward in time in loops of $6 \mathrm{~h}$ up to 10 days. Along the paths the $(E-P)>0$ values were computed and monthly average patterns are shown in Figure 4. These patterns are considered effective moistures sources for $P$ over the CRZs of the NRB. During January, the moisture uptake principally occurs over the southern half of the NRB, the surrounding Sahel and a small region on the Atlantic Ocean adjacent to WA. From February to April, the $P$ migrates northward and increases over the NRB and simultaneously the pattern $(E-P)>0$ occurs. In addition, the extension $(E-P)>0$ increases along the Sahel region and over the North and South Atlantic Ocean. During these months the most intense $(E-P)>0$ values are in the south-eastern NRB, suggesting that local evaporation could result in precipitation within the NRB, confirming the importance of recycling widely documented in the Sahel region. From May to September, the pattern of $(E-P)>0$ drastically enlarges over the South Atlantic Ocean, in particular during July and August, the rainiest months, while the opposite occurs in the tropical North Atlantic Ocean near WA. This result is not consequent with Druyan et al. [5], who argued that the tropical North Atlantic Ocean contributes the most rainfall to the western Sahel including the NRB. From May to October also highlights the intensity of $(E-P)>0$ patterns over the Mediterranean Sea, Red Sea and Northeast Africa. During this period the atmospheric moisture reaches the NRB from the northeast [11]. During November and December, when $P$ was previously over the southern NRB, the spatial pattern of $(E-P)>0$ also decreases and comprises just the continental regions of West Africa and the Sahel. Implementing the same model, Sori et al. [11] also identified NRB moisture sources but at a seasonal scale; however, they computed the moisture uptake on backward trajectories of all parcels residing over the NRB instead of considering those losing humidity, as in this study. Therefore, the results obtained here are more accurate and better explain the moisture-sink relationship. The location of the moisture sources here identified also match the position of seasonal moisture sources obtained by Sori et al. [11]; although, by considering a monthly scale in this study the moisture sources here obtained represent better the rainfall annual cycle over the NRB.

From a eularian perspective, Lelé et al. [80] utilised the vertically integrated moisture flux (VIMF) (from the surface to $850 \mathrm{hPa}$ ) to account for the total low-level moisture flux contribution to rainfall over WA at time scales ( $<10$ days) for assessing the role convergence by the mean circulation and ( $>10$ days) for the synoptic and climate-scale anomalies. They found that climatic anomalies are responsible for driving moisture northward from the Atlantic Ocean to the Guinea coast and westward from the western Atlantic Ocean into the Sahel, while the synoptic anomalies contribute to zonally transporting moisture out of the Sahel. During our experiment, we utilised positive values of the budget of $(E-P)$ (moisture absorption) calculated 10 days backward in time for each day but averaged over 1 month, combining both climatic signals, the mean circulation and climate-scale anomalies.

A schematic representation of these regions considered the most important moisture sources at the threshold of $(E-P)=0.1 \mathrm{~mm} /$ day as shown in Figure 5. The location and spatial extension of the sources represent the most efficient pathway of moisture transport to precipitation over the NRB. Moisture sources are divided into continental and oceanic, to separately determine the importance of the origin of air masses that lose humidity over the CRZs in the NRB. The continental regions include part of the NRB, West Africa (WA), Northeast Africa (NEA), Central Equatorial Africa (CEA), the Mediterranean part of Europe (EU) and part of the Arabian Peninsula (AP). The oceanic sources are the North Atlantic region west of WA (NATL), a region of the South-eastern Atlantic (SATL), the Mediterranean Sea (MS) and the Red Sea (RS). 


\section{$(\mathrm{E}-\mathrm{P})>0$}
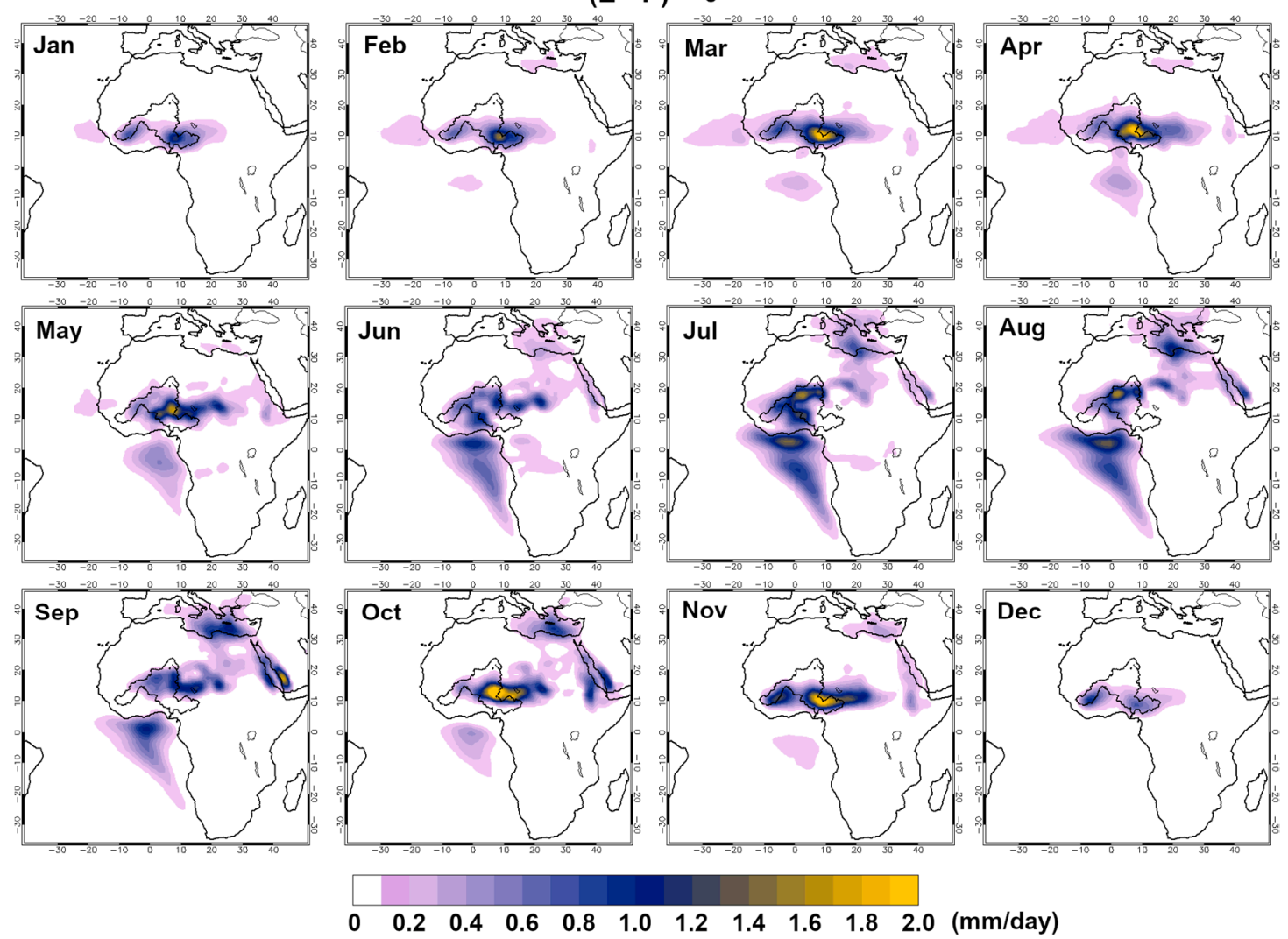

Figure 4. Monthly patterns of $(E-P)>0$ computed on backward trajectories over 10 days on air masses that lost humidity over each CRZ shown in Figure 2.
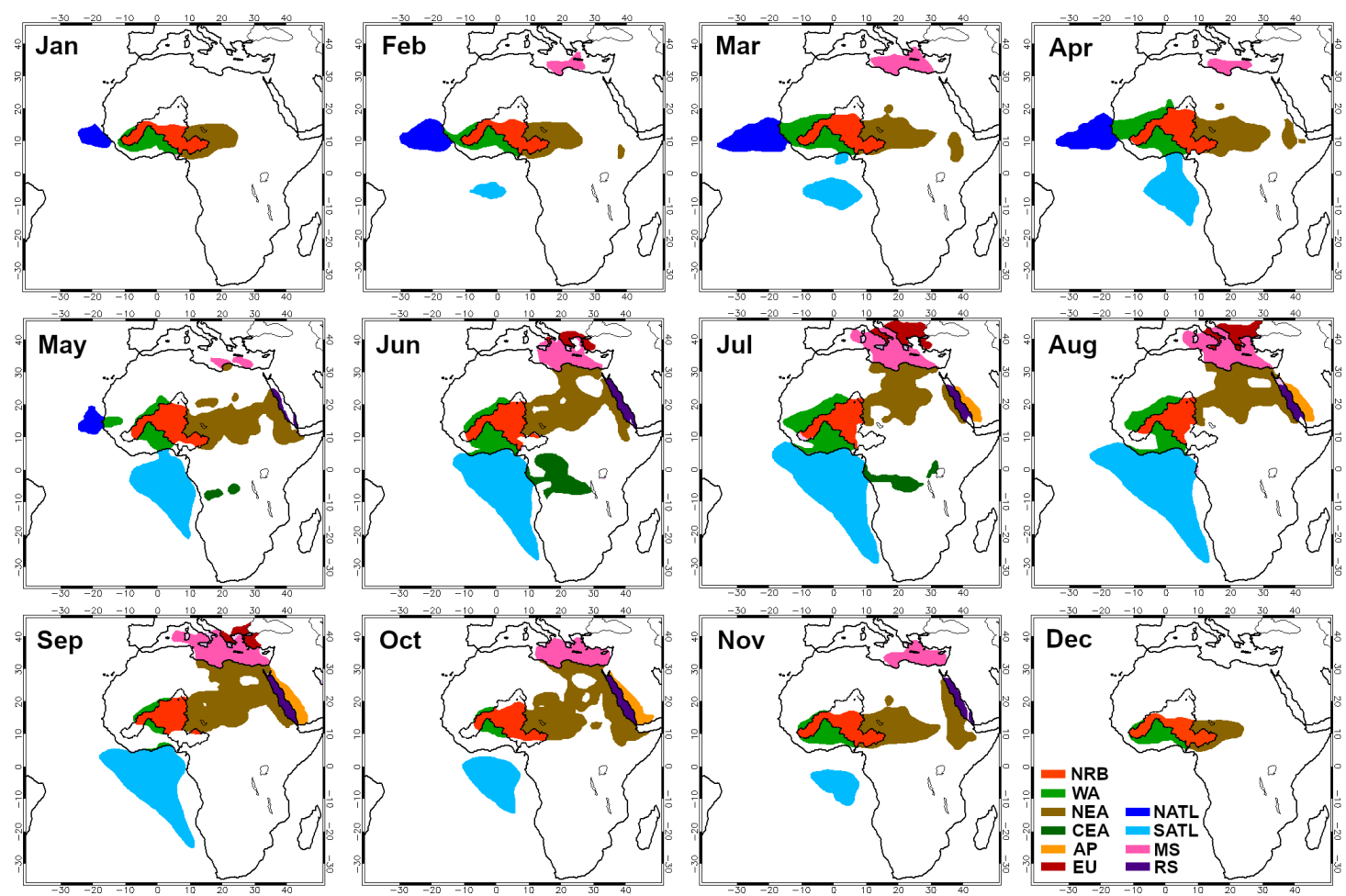

Figure 5. Schematic representation of relevant moisture sources for precipitation on the CRZs (shown in Figure 2) according to $(E-P)>0.1 \mathrm{~mm} /$ day shown in Figure 4. 
Moisture Uptake from the Sources

Once the sources were delimited in the backward modelling, we computed the total monthly moisture uptake over each and expressed it as a percentage of the total mean moisture uptake from all sources that contribute to $P$ over the CRZs. The results are listed in Table 1 and permit establishment of the primarily role of the sources in the moisture contribution to $P$ over the CRZs. Most of the moisture loss over the CRZs during January is taken up from part of the NRB, followed by the NEA and WA. From the oceanic source NATL, the moisture uptake represents only $6.7 \%$ of the total during this month. This suggests that high land evaporation likely contributes to the increased moisture uptake and hence the shape of the moisture source pattern observed along the Sahelian region (shown in Figure 4). During the following months until April, part of the NRB remains as the most important source of moisture followed by the NEA. According to the percentage values listed in Table 2 and $(E-P)>0$ (shown in Figure 4), the moisture uptake from SATL is crucial during the rainy season. During August, the rainiest month, the SATL provides 39.3\% of the total moisture uptake of air masses that lose humidity over the CRZs. Indeed, August is the only month during which greater than $50 \%$ of the moisture uptake originates from oceanic sources. This result agrees with previous studies describing the largest dependency of the Sahel rainfall on continental moisture origin [81-83]. Moisture uptake from other oceanic sources such as the MS or NATL or continental sources such as EU and AP do not represent high percentages compared to the total. Following August, as shown in Figure 4, the spatial pattern of $(E-P)>0$ drastically decreases over the oceans and therefore the total percentages of moisture uptake from oceanic sources decreases (Table 2). The aforementioned information and that described in Table 2 illustrates a mechanism in which the recycling process provides importance to continental moisture sources during the dry season. Druyan and Koster [5] investigated the Western Sahel moisture sources using diagnostic procedures integrated into the code of the Climate Model II of the Goddard Institute for Space Studies (GISS) during two June-July drought and rainy simulations. However, another approach could be to consider in advance the location of the NRB moisture sources and their role for precipitation over the basin to configure weather forecast and regional climate models in order to reduce the rainfall forecast uncertainties in the NRB and WA.

Table 2. Monthly percentage of moisture uptake (in percentage) from each moisture source compared to the total. The shaded cells in light brown (light blue) indicate when the major moisture uptakes originates from continental (oceanic) sources. Period: 1980-2017.

\begin{tabular}{ccccccccccccc}
\hline Sources & & \multicolumn{10}{c}{ Months } \\
\hline Continental & Jan & Feb & Mar & Apr & May & Jun & Jul & Aug & Sep & Oct & Nov & Dec \\
\hline NRB & 51.5 & 43.8 & 36.9 & 34.2 & 27.1 & 17.8 & 16.6 & 13.3 & 13.0 & 23.1 & 35.0 & 59.3 \\
WA & 14.9 & 12.2 & 13.1 & 13.9 & 9.0 & 10.1 & 11.7 & 7.5 & 2.4 & 2.5 & 10.8 & 20.9 \\
NEA & 26.9 & 25.1 & 26.9 & 30.6 & 37.4 & 24.5 & 15.9 & 17.8 & 31.7 & 36.6 & 40.7 & 19.8 \\
CEA & & & & & & 5.6 & 2.3 & & & & & \\
EU & & & & & & 1.1 & 2.5 & 2.1 & 0.9 & & & \\
AP & & & & & & & 1.5 & 2.7 & 6.0 & 5.1 & & $\mathbf{1 0 0}$ \\
Total & $\mathbf{9 3 . 3}$ & $\mathbf{8 1 . 1}$ & $\mathbf{7 6 . 9}$ & $\mathbf{7 8 . 7}$ & $\mathbf{7 3 . 5}$ & $\mathbf{5 9 . 1}$ & $\mathbf{5 0 . 5}$ & $\mathbf{4 3 . 4}$ & $\mathbf{5 4 . 0}$ & $\mathbf{6 7 . 3}$ & $\mathbf{8 6 . 5}$ & $\mathbf{1 0 0}$ \\
Oceanic & & & & & & & & & & & & \\
NATL & 6.7 & 11.3 & 9.1 & 6.4 & 3.2 & & & & & & & \\
SATL & & 3.8 & 8.6 & 13.3 & 21.9 & 33.9 & 39.3 & 42.3 & 25.6 & 13.3 & 5.0 & \\
MS & & 3.8 & 5.4 & 1.7 & 1.4 & 5.0 & 8.9 & 12.4 & 16.2 & 15.0 & 6.1 & \\
RS & & & & & & 2.0 & 1.3 & 1.9 & 4.2 & 4.4 & 2.4 & \\
Total & $\mathbf{6 . 7}$ & $\mathbf{1 8 . 9}$ & $\mathbf{2 3 . 1}$ & $\mathbf{2 1 . 3}$ & $\mathbf{2 6 . 5}$ & $\mathbf{4 0 . 9}$ & $\mathbf{4 9 . 5}$ & $\mathbf{5 6 . 6}$ & $\mathbf{4 6 . 0}$ & $\mathbf{3 2 . 7}$ & $\mathbf{1 4 . 5}$ & \\
\hline
\end{tabular}

\subsection{Identification of Dry and Wet Conditions in the CRZs}

The temporal evolution of the SPI1 is individually for each CRZ as shown in Figure 2 and for the period 1980-2017, in Figure 5. It has been documented that a strong connection occurs between the SPI over short time scales and temporal variations in soil moisture, which regulate the water availability 
for vegetation and agricultural activities [84]. In addition, soil moisture responds to precipitation variability but also affects precipitation through evaporation in WA [85]. Furthermore, soil moisture can be modulated because of land use activities. The land-surface-atmosphere feedbacks are highly valuable for land use management in the context of climate change [86]. Figure 5 shows the respective monthly SSMA for each CRZ. The analysis focused on individual months and CRZs with different spatial extensions, which prevents describing a natural and continuous evolution of the SPI1 and SSMA; however, it does permit one to focus on the impact of rainfall variability over each CRZ in the NRB. Dry conditions according to negative SPI1 values prevailed during January for the period 1981-1995, with severely and extremely dry conditions occurring during 1983, 1984, 1989, 1993 and 1995. Special attention has been given by researchers to the 1983-1984 period, documented as the most extreme drought that occurred in the Sahel during the last 50 years [32]. SPI1 values higher (lower) than $2.00(-2.00)$ are mainly observed during climatological dry months. However, only values between \pm 2.33 can be accepted, as they denote accumulated probabilities of 0.99 and 0.01 and return periods of one event over 100 years [87]. In any case, those SPI1 values greater (less) than $2.33(-2.33)$ such as the SPI1 for January 1983 can be considered to represent extreme wet (dry) events [67]. The SSMA on the CRZ of January does not very well follow the SPI1 variations. Consequently, the correlations between both variables are positive but very low. This suggests that rather than $P$ other variables such as temperature, wind velocity or evaporation could play a determinant role in agricultural activities. For February, the magnitudes of SPI1 values show severely dry conditions during 1983 and 1984 and extremely dry during 1997 and 2000. For this month, the correlation between SPI1 and SSMA increased, reaching 0.40 .

March is highlighted for 1983 and 1990 because of the severely dry conditions, as well as for continued dry conditions from 1997 to 2001, according to the negative SPI1 values. The rainfall deficit during this month could clearly affect the surface soil moisture content, as can be appreciated by SSMA and a correlation of 0.83 . April is also frequently affected by dry conditions between 1980 and 1993 and predominantly wet from 1993 to 2002. The correlation between the SPI1 and SSMA is high (0.74) during this month. The variability of the SPI1 for both months decreased after the year 2000. The remainder of the months are clearly affected by dry conditions during the 1980s. The correlations between the SPI1 and SSMA remain positive until November. It has been documented that soil moisture contributes to rainfall predictability at the end and immediately after the rainy season over the Sahel, through positive soil-precipitation feedback [85]. In monsoonal regions, during the rainiest months the wet soil moisture increases the net surface radiation and the total heat flux from the surface leading to a larger boundary layer with moist static energy that favours local rainfall $[88,89]$. However, during December, when the CRZ occupies the southern NRB, the $P$ is very low and correlations between the SPI1 and SSMA is negative. As previously discussed, other variables rather than $P$ could be responsible for modifying the soil moisture content. Oloruntade et al. [90] applied two meteorological drought indices, the SPI and the Standardised Precipitation-Evapotranspiration index (SPEI) and a hydrological drought index, the Standardised Runoff Index (SRI) [91], to investigate the occurrence of droughts in the Niger-South basin, a sub-catchment of the NRB in Nigeria, from 1970 to 2008 . They obtained very similar results to those presented here. They also found a higher agreement between the SRI and SPEI, suggesting that hydrological droughts are more affected by temperature (warming) than precipitation (drying) in this basin. Even though the CRZs are of different sizes, as shown in Figure 6, for all months but more clearly from August to December, there is a recovery of wet conditions within the NRB after approximately the year 2000. During December, similar to January, the $P$ is restricted to the southern NRB and the evolution of the SPI1 is very similar, as is the correlation with SSMA, that is, low and even becoming negative. 


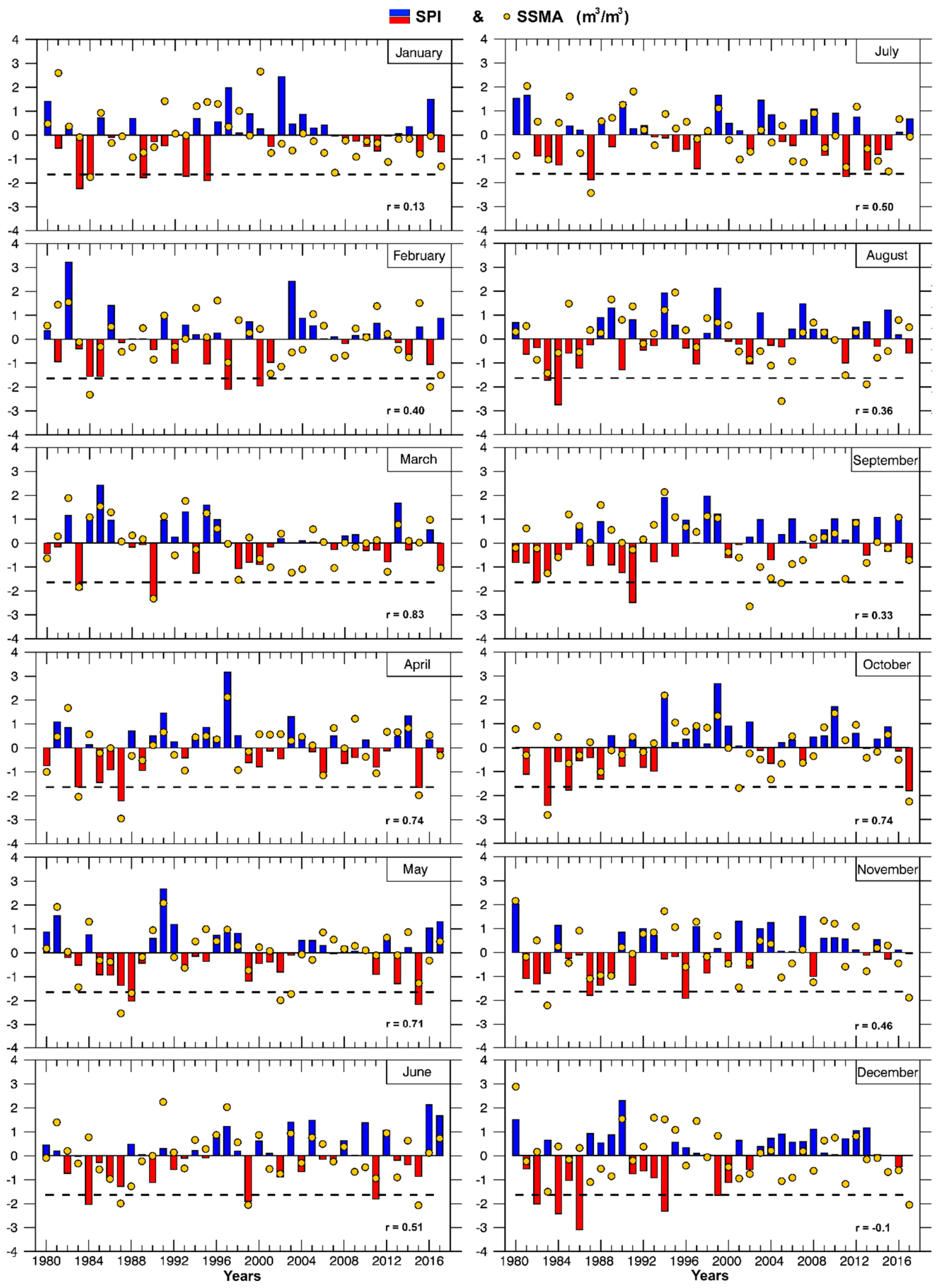

Figure 6. Monthly SPI1 (blue and red bars) and Surface Soil Moisture anomaly (SSMA) (orange circles).

Period: 1980-2017.

\subsection{Moisture Uptake and SPI1 Relationship}

A correlation analysis of the SPI 1 was computed for each CRZ, with the standardised anomalies of $(E-P)>0$ series obtained from the respective CRZ moisture sources. The results are shown in Figure 7 . During December, January and February, dry(wet) conditions according to the negative(positive) CRZ 
SPI1 values are best associated with the moisture uptake from the continental sources (e.g., NRB, WA and NEA). In contrast, $r$ values between the SPI1 and standardised anomalies of $(E-P)>0$ from SATL are positive (and greater than 0.4 during February, April, July, August and November). During August, the rainiest month, negative correlations prevail while a major positive correlation occurs for the SPI1 with the moisture uptake anomalies from the SATL. These results confirm a strong well-documented relationship between moisture supply from the tropical south Atlantic Ocean and rainfall variability over the NRB and so WA. In contrast, monthly persistent negative correlations obtained for the moisture uptake from the EU and MS with the SPI1 indicate that these remote sources may be responsible for providing moisture for precipitation over the NRB when the southward moisture reaching the CRZs decreases. Nevertheless, other authors (e.g., [9,92]) argue that an increase in $P$ over the Sahel is related to a warmer Mediterranean Sea. Regarding this, our results also show that moisture uptake from the MS contributes to $P$ over the NRB; however, in our approach, there is no linear positive relationship between rainfall on the CRZs of the NRB and moisture uptake from the MS. According to the correlation matrix (Figure 7), the series of $(E-P)>0$ from the sources are source of information that could improve the probabilistic monthly or seasonal forecasting of droughts in the $\mathrm{NRB}$, something that until now we have no knowledge that has been done in many previous works (e.g., $[7,93,94])$ for drought forecasting in the NRB or Africa.

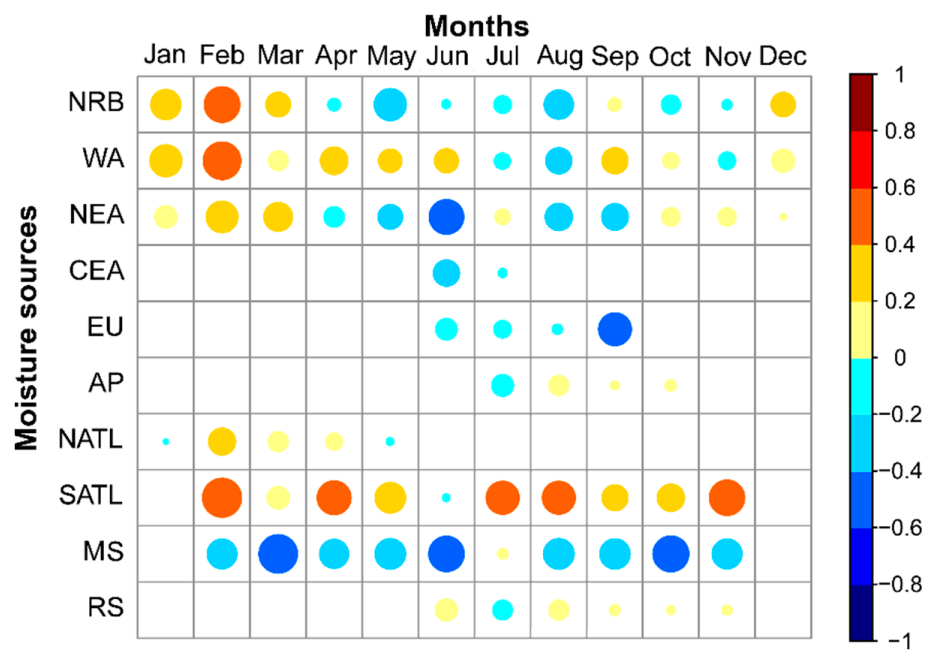

Figure 7. Monthly correlations between the SPI1 and $(E-P)>0$ (a) and SSMA and $(E-P)>0$ (b). The SPI1 and SSMA were computed for each CRZ and $(E-P)>0$ from each climatological moisture source, respectively. The blank boxes indicate there is not a moisture source during the month.

Roles of the Sources during Extremely Dry Conditions

Figure 8 shows those sources from which occur negative anomalies of moisture uptake during extremely dry conditions in the CRZs of the NRB. The dates when SPI1 reaches values less than -1.65 are also shown. Negative anomalies of $(E-P)>0$ during extremely dry conditions indicate a reduction in the moisture uptake by air parcels before losing humidity over the CRZs of the NRB. The NRB, WA and SATL are highlighted because of their persistent negative anomalies of moisture uptake. The NEA seems to play an important role during the driest months but from October to April. None of the composites show negative anomalies for moisture uptake from the EU and only during September of 1982 and 1981 was a reduction in moisture uptake observed from the MS.

Observational evidence for the Sahel and WA shows positive vegetation-rainfall feedback at a seasonal to interannual time scale associated with moisture recycling [95]. It has been documented for the North American monsoon system (NAMS) that evaporation and soil wetness time series tend to track similarly to precipitation [96] and therefore the positive feedback between monsoonal precipitation and the following $P$ increase is of a recycled origin [97]. Diverse spatial and temporal 
feedbacks are involved in the whole hydrological cycle of monsoonal regions. As we focused on extremely dry conditions, it could be expected that a reduction in $P$ over the NRB during the dry season enhanced the evapotranspiration. To assess this, we calculated PET anomalies in those regions within the NRB considered moisture sources (shown in Figure 5) for the composites of months affected by extremely dry conditions in which also occurred a decrease in the moisture uptake from the basin. A schematic representation of negative and positive anomalies of PET as downward and upward red arrows, respectively, is shown in Figure 8. The results show negative anomalies of PET for composites of November, December, January and February. The CRZs of these months are restricted to the southern NRB (Figure 2) and the average $P$ is very low (Figure 3). In contrast, in the remainder of the composites in which the moisture uptake from the basin to $P$ over the basin is reduced, positive PET anomalies occur. This suggests that water vapour supplied to the atmosphere because enhanced PET during extremely dry conditions could be transported outside the basin to remote regions. A modelling experiment could be an appropriate tool to illustrate and clarify the relative impact of continental evapotranspiration anomalies on local rainfall.

\begin{tabular}{|c|c|c|c|c|c|c|c|c|c|c|}
\hline \multirow[b]{2}{*}{ Dates } & \multicolumn{10}{|c|}{ Sources } \\
\hline & NRB & WA & NEA & CEA & EU & AP & NATL & SATL & MS & RS \\
\hline Jan/1983,1984,1989,1993,1995 & $\nabla \downarrow$ & $\nabla$ & $\nabla$ & & & & & & & \\
\hline $\mathrm{Feb} / 1997,2000$ & $\nabla \downarrow$ & $\nabla$ & $\nabla$ & & & & $\nabla$ & $\nabla$ & & \\
\hline Mar/1990,1983 & $\nabla \uparrow$ & $\nabla$ & $\nabla$ & & & & & $\nabla$ & & \\
\hline Apr/1987,2015 & $\nabla \uparrow$ & $\nabla$ & $\nabla$ & & & & $\nabla$ & $\nabla$ & & \\
\hline May/2015,1988 & & & & & & & & $\nabla$ & & \\
\hline Jun/1984,1999, 2011 & $\nabla \uparrow$ & $\nabla$ & & & & & & $\nabla$ & & $\nabla$ \\
\hline $\mathrm{Jul} / 1987,2011$ & $\nabla \uparrow$ & $\nabla$ & & $\nabla$ & & $\nabla$ & & & & $\nabla$ \\
\hline Aug/1984,1983 & & $\nabla$ & & & & $\nabla$ & & $\nabla$ & & $\nabla$ \\
\hline Sep/1991,1982 & $\nabla \uparrow$ & $\nabla$ & & & & $\nabla$ & & $\nabla$ & $\nabla$ & $\nabla$ \\
\hline Oct/1983,2017,1985 & $\nabla \uparrow$ & & $\nabla$ & & & & & $\nabla$ & & \\
\hline Nov/1986,1987 & $\nabla \downarrow$ & & $\nabla$ & & & & & $\nabla$ & & \\
\hline Dec/1986,1984 & $\nabla \downarrow$ & $\nabla$ & $\nabla$ & & & & & & & \\
\hline
\end{tabular}

Figure 8. Moisture sources from which decreased the moisture uptake (triangles in blue) in composites of months affected by extremely dry conditions in CRZs of the NRB. Upward and downward red arrows indicate positive and negative anomalies, respectively, of PET.

The moisture losses $((E-P)<0)$ and the $P$ over the CRZs depends on driving mechanisms such as synoptic circulation patterns and local atmospheric conditions (e.g., temperature, pressure, winds). To better understand the mechanisms associated with extremely dry conditions and the associated reduction in the moisture uptake from the climatological moisture sources we analysed the VIMF and Omega anomalies as shown in Figure 9. From January to April, the VIMF anomalies indicate that atmospheric moisture flux reaches the CRZs predominantly from the northeast, although the magnitude of the VIMF anomalies during January is lower. A close anticyclonic circulation is shown by VIMF anomalies over north-western Africa and the Iberia Peninsula for the composites of February and April. The vertical cross-section of Omega from $5^{\circ} \mathrm{N}$ to $25^{\circ} \mathrm{N}$ along $5^{\circ} \mathrm{E}$ shows that positive anomalies mostly prevailed between $10^{\circ} \mathrm{N}$ to $15^{\circ} \mathrm{N}$ from January to March; thus, a descending motion progressively inhibited convection. However, from approximately $5^{\circ} \mathrm{N}$ to $10^{\circ} \mathrm{N}$ over the Guinean coast are observed positive anomalies of Omega, which mean that ascending motions prevail but are approximately restricted from $1000 \mathrm{mb}$ to $700 \mathrm{mb}$. Intense downward motions according to positive anomalies of Omega also occur northward of $10^{\circ} \mathrm{N}$ for the composited of extremely dry Aprils. From January to April negative anomalies of Omega, thus ascending motions are observed on the low troposphere, from $5^{\circ} \mathrm{N}$ to $10^{\circ} \mathrm{N}$. 


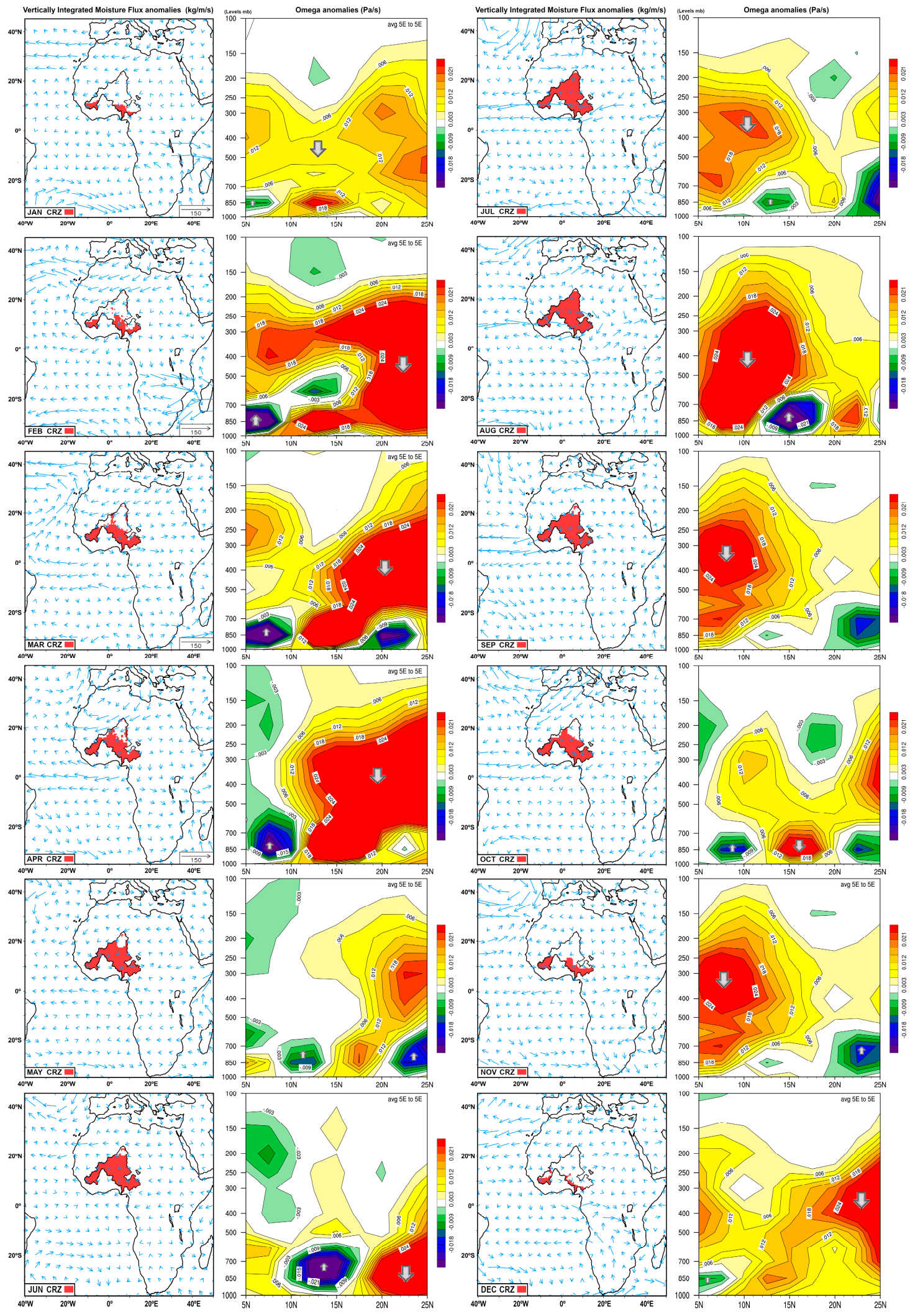

Figure 9. Vertically integrated moisture flux (VIMF) anomalies (blue vectors) and Omega (vertical velocity) (shaded) for composites of months under extremely dry conditions in the CRZs. Downward and upward arrows indicate the predominant vertical atmospheric motion according to the Omega anomalies. 
From May to September, a northward displacement of ascending motions but closely restricted between $10^{\circ} \mathrm{N}$ to $15^{\circ} \mathrm{N}$ occurs and is limited to the low atmosphere (normally below $650 \mathrm{mb}$ ). Thus suggests a schematic overview of favourable locations for $P$. Progressive intense inhibition of the ascending convective movements are best observed south of $10^{\circ} \mathrm{N}$ and north of $15^{\circ} \mathrm{N}$ from June to August. In addition, the latitudinal anomalies of Omega show that may exist a dipole-type wet (dry) Guinea coast and associated dry (wet) Sahel, that has been related to sea surface temperature anomalies over the tropical South Atlantic Ocean (e.g., [98]). The VIMF anomalies illustrate a decrease in moisture transport from the southeast and south Atlantic to the CRZs during these months. Many studies have been completed regarding this behaviour. In the equatorial zone, the ITCZ plays a key role. From November to April (the austral summer), it moves southward and a rainfall reduction occurs over the NRB. An anomalous position northward may favour the contribution of humidity from the South Atlantic Ocean to the NRB and WA. An important mechanism explains how positive SST anomalies in the South Atlantic Ocean weaken the sea level pressure gradient between the ocean and land and hence produce a weaker ITCZ shift displaced southward during dry years over the Sahel, decreasing the rainfall over the Sahel and WA [61,62]. Okonkwo et al. [99] also found an association between the Tropical Easterly Jet (TEJ) and El Niño events during the 1980s led to intense drought in the Sahel region of WA during the boreal summer months. A more detailed analysis should be completed to assess any possible impact of low-level jets on the atmospheric moisture transport across the Sahel and WA. Precisely, an important feature also observed in VIMF anomaly patterns from July to October is the westward intense anomalies over WA extending over the equatorial Atlantic Ocean. For extreme rainfall events in WA, Ta et al. [100] found the contrary; VIMF is dominant to the east and it penetrates into WA mainly from the equatorial Atlantic Ocean.

The VIMF anomalies for composites of extremely dry months of October, November and December, show an anticyclonic circulation centred in the North Atlantic Ocean to the west of the Iberian Peninsula. It may be responsible for VIMF from the north and northeast reaching the NRB, particularly in October and November. In December the VIMF anomalies from the west are observed over practically all the basin. The latitudinal cross section of Omega anomalies shows that positive values and therefore descendant motions prevail and almost affect all latitudes in December.

\section{Conclusions}

In this study we identified the most relevant moisture sources for precipitation over the NRB. To do so we delimited the monthly CRZs within the NRB, from which we tracked backward in time those air parcels that lost moisture $((E-P)<0)$. To do it global outputs of Lagrangian model FLEXPART was used. It permitted us to compute the moisture uptake $((E-P)>0)$ integrated into the vertical along the backward trajectories, allowing the identification of the most relevant moisture sources for precipitation in the NRB. According to $(E-P)>0$ patterns, the NRB receives humidity from both hemispheres and the spatial extension of the sources increases following the precipitation annual cycle. The moisture uptake for precipitation is particularly important from continental sources mainly during the climatological dry months. Among the oceanic sources, the south Atlantic Ocean provides humidity for precipitation over the NRB during nearly the entire year but is particularly responsible for a large part of the total moisture uptake during the rainiest months (e.g., June, July and August). A correlation analysis between series of $(E-P)>0$ from each source and the SPI at a temporal scale of one month for each CRZ confirmed these results. Besides, although previous findings argue that moisture transported from warmer SSTs in the Mediterranean Sea play an important role for rainfall in WA, we found negative correlations between the moisture uptake from this source and the SPI1 for CRZs. The SPI1 was indeed utilised to identify dry and/or wet conditions in CRZs. As has been widely documented, the 1980s are notable for dry conditions, also appreciated because negative surface soil moisture negative anomalies. However, we found no strong linear relationship between the deficit / excess rainfall according to the SPI1 values and the surface soil moisture anomalies during 
the climatologically drier months of December and January, while in contrast, during the remaining months exist a positive feedback relationship.

Composites of months for extremely dry conditions in the CRZs were utilised to determine the role of the sources. The results show the important role of moisture uptake from the surrounding continental sources and the tropical south Atlantic Ocean. The latitudinal cross section of Omega anomalies shows the prevalence of descending air motions according to extremely dry conditions but ascending motions can be also appreciated in the lower troposphere moving latitudinally as the precipitation does over the NRB. Considering these results additional research is ongoing to compute the moisture uptake by tracking backward in time the air parcels losing humidity in the low troposphere of CRZs and determine the role of the sources during wet extremes. The moisture sources identified here should be considered as a tool to investigate detailed insight into the causes of rainfall variability and hydroclimatological extremes that have occurred during recent decades in the NRB but particularly for modelling studies and future climatic scenarios, of great importance for the socioeconomic development of the countries and inhabitants of the basin.

Author Contributions: R.N. and L.G. designed, proposed and conducted the research; R.S. performed the experiments; R.S., R.N. and L.G. analysed the data; R.S., R.N., L.G., M.S. and A.D. wrote the paper.

Funding: This research was funded by the Spanish Government (Ministerio de Economía, Industria y Competitividad) and the European Regional Development Fund of the European Commission (in Spanish, FEDER) through the SETH project (CGL2014-60849-JIN). This research was partially supported by Xunta de Galicia under project ED413C 2017/64 “Programa de Consolidacion e Estructuracion de Unidades de Investigacion Competitivas (Grupos de Referencia Competitiva)" co-funded by the European Regional Development Fund (FEDER).

Acknowledgments: The authors acknowledge the financial support above mentioned and the useful comments and suggestions of the two anonymous reviewers.

Conflicts of Interest: The authors declare no conflict of interest. The founding sponsors had no role in the design of the study; in the collection, analyses or interpretation of data; in the writing of the manuscript; or in the decision to publish the results.

\section{References}

1. Oyerinde, G.T.; Hountondji, F.C.C.; Wisser, D.; Diekkruger, B.; Lawin, A.E.; Odofin, A.J.; Afouda, A. Hydro-climatic changes in the Niger basin and consistency of local perceptions. Reg. Environ. Chang. 2015, 15, 1627-1637. [CrossRef]

2. Zhang, W.; Brandt, M.; Guichard, F.; Tian, Q.; Fensholt, R. Using long-term daily satellite based rainfall data (1983-2015) to analyze spatio-temporal changes in the sahelian rainfall regime. J. Hydrol. 2017, 550, 427-440. [CrossRef]

3. Lebel, T.; Diedhiou, A.; Laurent, H. Seasonal cycle and interannual variability of the Sahelian rainfall at hydrological scales. J. Geophys. Res. 2003, 108, 1401-1411. [CrossRef]

4. Nicholson, S.E. The West African Sahel: A Review of Recent Studies on the Rainfall Regime and Its Interannual Variability. ISRN Meteorol. 2013, 2013, 453521. [CrossRef]

5. Druyan, L.M.; Koster, R.D. Sources of Sahel Precipitation for Simulated Drought and Rainy Seasons. J. Clim. 1989, 2, 1438-1446. [CrossRef]

6. Pu, B.; Cook, K.H. Role of the West African westerly jet in Sahel rainfall variations. J. Clim. 2012, 25, $2880-2896$. [CrossRef]

7. Rodríguez-Fonseca, B.; Mohino, E.; Mechoso, C.R.; Caminade, C.; Biasutti, M.; Gaetani, M.; Garcia-Serranog, J.; Vizyh, E.K.; Cookh, K.; Xue, Y.; et al. Variability and Predictability of West African Droughts: A Review on the Role of Sea Surface Temperature Anomalies. J. Clim. 2015, 28, 4034-4060. [CrossRef]

8. Wang, S.; Gillies, R.R. Observed change in Sahel rainfall, circulations, African easterly waves, and Atlantic hurricanes since 1979. Int. J. Geophys. 2011, 2011, 259529. [CrossRef]

9. Fontaine, B.; Roucou, P.; Gaetani, M.; Marteau, R. Recent changes in precipitations, ITCZ convection and northern tropical circulation over North Africa (1979-2007). Int. J. Climatol. 2011, 31, 633-648. [CrossRef] 
10. Van der Ent, R.J. A New View on the Hydrological Cycle over Continents. Ph.D. Thesis, Delft University of Technology, Delft, The Netherlands, 2014.

11. Sorí, R.; Nieto, R.; Drumond, A.; Gimeno, L. The Niger River Basin Moisture Sources: A Lagrangian Analysis. Atmosphere 2017, 8, 38. [CrossRef]

12. Okpara, J.N.; Tarhule, A.A.; Perumal, M. Study of Climate Change in Niger River Basin, West Africa: Reality Not a Myth. Chapter 1. In Climate Change-Realities, Impacts Over Ice Cap, Sea Level and Risks; IntechOpen: Rijeka, Croatia, 2013. [CrossRef]

13. Adelekan, I.O.; Adegebo, B.O. Variation in onset and cessation of the rainy season in Ibadan. J. Sci. Res. 2014, 13, 13-21.

14. Dunning, C.M.; Black, E.C.; Allan, R.P. The onset and cessation of seasonal rainfall over Africa. J. Geophys. Res. Atmos. 2016, 121, 11405-11424. [CrossRef]

15. Odekunle, T.O.; Eludoyin, A.O. Sea surface temperature patterns in the Gulf of Guinea: Their implications for the spatio-temporal variability of precipitation in West Africa. Int. J. Climatol. 2008, 28, 1507-1517. [CrossRef]

16. Joly, M.; Voldoire, A. Role of the Gulf of Guinea in the inter-annual variability of the West African monsoon: What do we learn from CMIP3 coupled simulations? Int. J. Climatol. 2010, 30, 1843-1856. [CrossRef]

17. Ali, K.E.; Kouadio, K.Y.; Zahiri, E.-P.; Aman, A.; Assamoi, A.P.; Bourles, B. Influence of the Gulf of Guinea Coastal and Equatorial Upwellings on the Precipitations along its Northern Coasts during the Boreal Summer Period. Asian J. Appl. Sci. 2011, 4, 271-285. [CrossRef]

18. Nnamchi, H.C.; Li, J.; Kang, I.-S.; Kucharski, F. Simulated impacts of the South Atlantic Ocean Dipole on summer precipitation at the Guinea Coast. Clim. Dyn. 2013, 41, 677. [CrossRef]

19. Trenberth, K.E. Atmospheric Moisture Recycling: Role of Advection and Local Evaporation. J. Clim. 1999, 12, 1368-1381. [CrossRef]

20. Gong, C.; Eltahir, E.A.B. Sources of Moisture for Rainfall in West Africa. Water Resour. Res. 1996, 32, 3115-3121. [CrossRef]

21. Nieto, R.; Gimeno, L.; Trigo, R.M. A Lagrangian identification of major sources of Sahel moisture. Geophys. Res. Lett. 2006, 33, 1-6. [CrossRef]

22. van der Ent, R.J.; Savenije, H.H.G.; Schaefli, B.; Steele-Dunne, S.C. Origin and fate of atmospheric moisture over continents. Water Resour. Res. 2010, 46, W09525. [CrossRef]

23. Knoche, H.R.; Kunstmann, H. Tracking atmospheric water pathways by direct evaporation tagging: A case study for West Africa. J. Geophys. Res. Atmos. 2013, 118, 12345-12358. [CrossRef]

24. Arnault, J.; Knoche, R.; Wei, J.; Kunstmann, H. Evaporation tagging and atmospheric water budget analysis with WRF: A regional precipitation recycling study for West Africa. Water Resour. Res. 2016, 52, 1544-1567. [CrossRef]

25. DelSole, T.; Dirmeyer, P.; Zhao, M. Collaborative Research: Characterizing Land Surface Memory to Advance Climate Prediction; Annual Report: 0233320; Institute for Global Environmental Strategies: Hayama, Japan, 2009.

26. Kelemen, F.D.; Ludwig, P.; Reyers, M.; Ulbrich, S.; Pinto, J.G. Evaluation of moisture sources for the Central European summer flood of May/June 2013 based on regional climate model simulations. Tellus A Dyn. Meteorol. Oceanogr. 2016, 68, 29288. [CrossRef]

27. Ciric, D.; Nieto, R.; Ramos, A.M.; Drumond, A.; Gimeno, L. Wet Spells and Associated Moisture Sources Anomalies across Danube River Basin. Water 2017, 9, 615. [CrossRef]

28. Drumond, A.; Nieto, R.; Gimeno, L. A Lagrangian approach for investigating anomalies in the moisture transport during drought episodes. Cuadernos de Investigación Geográfica 2016, 42, 113-125. [CrossRef]

29. Sorí, R.; Nieto, R.; Drumond, A.; Vicente-Serrano, S.V.; Gimeno, L. A Lagrangian perspective of the hydrological cycle in the Congo River basin. Earth Syst. Dyn. 2017, 8, 653-675. [CrossRef]

30. Gimeno, L. Grand challenges in atmospheric science. Front. Earth Sci. 2013, 1, 1-5. [CrossRef]

31. Tallaksen, L.M.; Van Lanen, H.A. Hydrological Drought: Processes and Estimation Methods for Streamflow and Groundwater; Elsevier: Amsterdam, The Netherlands, 2004; Volume 48.

32. Masih, I.; Maskey, S.; Mussá, F.E.F.; Trambauer, P. A review of droughts on the African continent: A geospatial and long-term perspective. Hydrol. Earth Syst. Sci. 2014, 18, 3635-3649. [CrossRef]

33. Nicholson, S. On the question of the "recovery" of the rains in the West African Sahel. J. Arid Environ. 2005, 63, 615-641. [CrossRef] 
34. Okpara, J.N.; Tarhule, A. Evaluation of Drought Indices in the Niger Basin, West Africa. J. Geogr. Earth Sci. 2015, 3, 1-32. [CrossRef]

35. Hagos, S.M.; Cook, K.H. Ocean warming and late-twentieth-century Sahel drought and recovery. J. Clim. 2008, 21, 3797-3814. [CrossRef]

36. Gautier, D.; Denis, D.; Locatelli, B. Impacts of drought and responses of rural populations in West Africa: A systematic review. WIREs Clim. Chang. 2016, 7, 666-681. [CrossRef]

37. Sorí, R.; Marengo, J.; Nieto, R.; Drumond, A.; Gimeno, L. The Atmospheric Branch of the Hydrological Cycle over the Negro and Madeira River Basins in the Amazon Region. Water 2018, 10, 738. [CrossRef]

38. Stojanovic, M.; Drumond, A.; Nieto, R.; Gimeno, L. Anomalies in Moisture Supply during the 2003 Drought Event in Europe: A Lagrangian Analysis. Water 2018, 10, 467. [CrossRef]

39. Stojanovic, M.; Drumond, A.; Nieto, R.; Gimeno, L. Variations in Moisture Supply from the Mediterranean Sea during Meteorological Drought Episodes over Central Europe. Atmosphere 2018, 9, 278. [CrossRef]

40. Drumond, A.; Gimeno, L.; Nieto, R.; Trigo, R.M.; Vicente-Serrano, S.M. Drought episodes in the climatological sinks of the Mediterranean moisture source: The role of moisture transport. Glob. Planet. Chang. 2017, 151, 4-14. [CrossRef]

41. Food and Agriculture Organization of the United Nations (FAO). Irrigation Potential in Africa. A Basin Approach; FAO Land and Water Bulletin: Roma, Italy, 1997; Volume 4.

42. Lienou, G.; Mahe, G.; Dieulin, C.; Paturel, J.E.; Bamba, F.; Sighomnou, D.; Dessouassi, R. The River Niger water availability: Facing future needs and climate change. In Global Change: Facing Risks and Threats to Water Resources, Proceedings of the Sixth World FRIEND Conference, Fez, Morocco, 25-29 October 2010; IAHS Publ. 340; IAHS Press: Wallingford, UK, 2010.

43. Andersen, I.; Dione, O.; Jarosewich-Holder, M.; Olivry, J.-C. The Niger River Basin: A Vision for Sustainable Management; World Bank: Washington, DC, USA, 2005.

44. Kottek, M.; Grieser, J.; Beck, C.; Rudolf, B.; Rubel, F. World Map of the Köppen-Geiger climate classification updated. Meteorol. Z. 2006, 15, 259-263. [CrossRef]

45. Food and Agriculture Organization of the United Nations (FAO). Disaster Risk Management Strategy in West Africa and the Sahel (2011-2013); FAO: Rome, Italy, 2011.

46. Chou, C.; Chen, C.A.; Tan, P.H.; Chen, K.T. Mechanisms for global warmingimpacts on precipitation frequency and intensity. J. Clim. 2012, 25, 3291-3306. [CrossRef]

47. Deni, S.M.; Jemain, A.A.; Ibrahim, K. The spatial distribution of wet and dry spells over Peninsular Malaysia. Theor. Appl. Climatol. 2008, 94, 163-173. [CrossRef]

48. Nandargi, S.; Mulye, S.S. Relationships between rainy days, mean daily intensity, and seasonal rainfall over the Koyna catchment during 1961-2005. Sci. World J. 2012, 2012, 894313. [CrossRef] [PubMed]

49. Stohl, A.; James, P. A Lagrangian analysis of the atmospheric branch of the global water cycle. Part 1: Method description, validation, and demonstration for the August 2002 flooding in central Europe. J. Hydrometeorol. 2004, 5, 656-678. [CrossRef]

50. Stohl, A.; James, P. A Lagrangian analysis of the atmospheric branch of the global water cycle: 2 . Earth's river catchments, ocean basins, and moisture transports between them. J. Hydrometeorol. 2005, 6, 961-984. [CrossRef]

51. Seibert, P.; Frank, A. Source-receptor matrix calculation with a Lagrangian particle dispersion model in backward mode. Atmos. Chem. Phys. 2004, 4, 51-63. [CrossRef]

52. Numaguti, A. Origin and recycling processes of precipitating water over the Eurasian continent: Experiments using an atmospheric general circulation model. J. Geophys. Res. 1999, 104, 1957-1972. [CrossRef]

53. Gimeno, L.; Stohl, A.; Trigo, R.M.; Dominguez, F.; Yoshimura, K.; Yu, L.; Drumond, A.; Durán-Quesada, A.M.; Nieto, R. Oceanic and terrestrial sources of continental precipitation. Rev. Geophys. 2012, 50, RG4003. [CrossRef]

54. Stojanovic, M.; Drumond, A.; Nieto, R.; Gimeno, L. Moisture Transport Anomalies over the Danube River Basin during Two Drought Events: A Lagrangian Analysis. Atmosphere 2017, 8, 193. [CrossRef]

55. Dirmeyer, P.A.; Brubaker, K.L. Contrasting evaporative moisture sources during the drought of 1988 and the flood of 1993. J. Geophys. Res. 1999, 104, 19383-19397. [CrossRef]

56. Drumond, A.; Marengo, J.; Ambrizzi, T.; Nieto, R.; Moreira, L.; Gimeno, L. The role of the Amazon Basin moisture in the atmospheric branch of the hydrological cycle: A Lagrangian analysis. Hydrol. Earth Syst. Sci. 2014, 18, 2577-2598. [CrossRef] 
57. Bin, C.; Xu, X.-D.; Zhao, T. Main moisture sources affecting lower Yangtze River Basin in boreal summers during 2004-2009. Int. J. Climatol. 2013, 33, 1035-1046. [CrossRef]

58. Drumond, A.; Nieto, R.; Gimeno, L.; Ambrizzi, T. A Lagrangian identification of major sources of moisture over Central Brazil and La Plata Basin. J. Geophys. Res. Atmos. 2008, 113. [CrossRef]

59. Ciric, D.; Stojanovic, M.; Drumond, A.; Nieto, R.; Gimeno, L. Tracking the Origin of Moisture over the Danube River Basin Using a Lagrangian Approach. Atmosphere 2016, 7, 162. [CrossRef]

60. World Meteorological Organization. Standardized Precipitation Index User Guide; WMO-No. 1090; Svoboda, M., Hayes, M., Wood, D., Eds.; World Meteorological Organization: Geneva, Switzerland, 2012.

61. Heim, J.R. A review of twentieth-century drought indices used in the United States, B. Am. Meteorol. Soc. 2002, 83, 1149-1165. [CrossRef]

62. Zargar, A.; Sadiq, R.; Naser, B.; Khan, F.I. A review of drought indices. Environ. Rev. 2011, 19, 333-349. [CrossRef]

63. McKee, T.B.; Doesken, N.J.; Kleist, J. The relationship of drought frequency and duration to time scales. In Proceedings of the Eighth Conference on Applied Climatology, Anaheim, CA, USA, 17-22 January 1993; pp. 179-184.

64. Wu, H.; Svoboda, M.D.; Hayes, M.J.; Wilhite, D.A.; Wen, F. Appropriate application of the Standardized Precipitation Index in arid locations and dry seasons. Int. J. Climatol. 2007, 27, 65-79. [CrossRef]

65. Beguería, S.; Vicente-Serrano, S.M.; Reig, F.; Latorre, B. Standardized Precipitation Evapotranspiration Index (SPEI) revisited: Parameter fitting, evapotranspiration models, tools, datasets and drought monitoring. Int. J. Climatol. 2014, 34, 3001-3023. [CrossRef]

66. Fischer, T.; Gemmer, M.; Luliu, L.; Buda, S. Temperature and precipitation trends and dryness/wetness pattern in the Zhujiang River Basin, South China, 1961-2007, 1961-2007. Quat. Int. 2011, 244, 138-148. [CrossRef]

67. Guttman, N.B. Accepting the standardized precipitation index: A calculation algorithm. J. Am. Water Resour. Assoc. 1999, 35, 311-322. [CrossRef]

68. Agnew, C.T. Using the SPI to identify drought. Drought Netw. News 2000, 12, 6-12.

69. Dee, D.P.; Uppala, S.M.; Simmons, A.J.; Berrisford, P.; Poli, P.; Kobayashi, S.; Andrae, U.; Balmaseda, M.A.; Balsamo, G.; Bauer, P.; et al. The ERA-Interim reanalysis: Configuration and performance of the data assimilation system. Q. J. R. Meteorol. Soc. 2011, 137, 553-597. [CrossRef]

70. Rienecker, M.M.; Suarez, M.J.; Gelaro, R.; Todling, R.; Bacmeister, J.; Liu, E.; Bosilovich, M.G.; Schubert, S.D.; Takacs, L.; Kim, G.-K.; et al. MERRA: NASA's Modern-Era Retrospective Analysis for Research and Applications. J. Clim. 2011, 24, 3624-3648. [CrossRef]

71. Saha, S.; Moorthi, S.; Pan, H.; Wu, X.; Wang, J.; Nadiga, S.; Tripp, P.; Kistler, R.; Woollen, J.; Behringer, D.; et al. The NCEP Climate Forecast System Reanalysis. Bull. Am. Meteorol. Soc. 2010, 91, 1015-1058. [CrossRef]

72. Lorenz, C.; Kunstmann, H. The hydrological cycle in three state-of-the-art reanalyses: Intercomparison and performance analysis. J. Hydrometeorol. 2012, 13, 1397-1420. [CrossRef]

73. Copernicus Climate Change Service (C3S). ERA5: Fifth Generation of ECMWF Atmospheric Reanalyses of the Global Climate; Copernicus Climate Change Service Climate Data Store (CDS): Geneva, Switzerland, 2017.

74. Harris, I.; Jones, P.D.; Osborn, T.J.; Lister, D.H. Updated high-resolution grids of monthly climatic observations-The CRU TS3.10 Dataset. Int. J. Climatol. 2014, 34, 623-642. [CrossRef]

75. Martens, B.; Miralles, D.G.; Lievens, H.; van der Schalie, R.; de Jeu, R.A.M.; Fernández-Prieto, D.; Beck, H.E.; Dorigo, W.A.; Verhoest, N.E.C. GLEAM v3: Satellite-based land evaporation and root-zone soil moisture. Geosci. Model. Dev. 2017, 10, 1903-1925. [CrossRef]

76. Miralles, D.G.; Holmes, T.R.H.; de Jeu, R.A.M.; Gash, J.H.; Meesters, A.G.C.A.; Dolman, A.J. Global land-surface evaporation estimated from satellite-based observations. Hydrol. Earth Syst. Sci. 2011, 15, 453-469. [CrossRef]

77. Kalnay, E.; Kanamitsu, M.; Kistler, R.; Collins, W.; Deaven, D.; Gandin, L.; Iredell, M.; Saha, S.; White, G.; Woollen, J.; et al. The NCEP/NCAR 40-year reanalysis project. Bull. Am. Meteorol. Soc. 1996, 77, 437-470. [CrossRef]

78. Siegmund, J.; Bliefernicht, J.; Laux, P.; Kunstmann, H. Toward a seasonal precipitation prediction system for West Africa: Performance of CFSv2 and high-resolution dynamical downscaling. J. Geophys. Res. Atmos. 2015, 20. [CrossRef] 
79. Rodrigues, L.R.L.; García-Serrano, J.; Doblas-Reyes, F. Seasonal forecast quality of the West African monsoon rainfall regimes by multiple forecast systems. J. Geophys. Res. Atmos. 2014, 119, 7908-7930. [CrossRef]

80. Lélé, I.M.; Leslie, L.M.; Lamb, P.J. Analysis of Low-Level Atmospheric Moisture Transport Associated with the West African Monsoon. J. Clim. 2015, 28, 4414-4430. [CrossRef]

81. Zeng, N.; Neelin, J.D.; Lau, K.M.; Tucker, C.J. Enhancement of interdecadal climate variability in the Sahel by vegetation interaction. Science 1999, 286, 1537-1540. [CrossRef] [PubMed]

82. Dirmeyer, P.A.; Wei, J.; Bosilovich, M.G.; Mocko, D.M. Comparing evaporative sources of terrestrial precipitation and their extremes in MERRA using relative entropy. J. Hydrometeorol. 2014, 15, 102-116. [CrossRef]

83. Miralles, D.G.; Jiménez, C.; Jung, M.; Michel, D.; Ershadi, A.; McCabe, M.F.; Hirschi, M.; Martens, B.; Dolman, A.J.; Fisher, J.B.; et al. The WACMOS-ET project-Part 2: Evaluation of global terrestrial evaporation data sets. Hydrol. Earth Syst. Sci. 2016, 20, 823-842. [CrossRef]

84. Sims, A.P.; Nigoyi, D.S.; Raman, S. Adopting indices for estimating soil moisture: A North Carolina case study. Geophys. Res. Lett. 2002, 29, 1-4. [CrossRef]

85. Douville, H.; Conil, S.; Tuteca, S.; Voldoire, A. Soil moisture memory and West African monsoon predictability: Artefact or reality? Clim. Dyn. 2007, 28, 723-742. [CrossRef]

86. Savenije, H.H. The runoff coefficient as the key to moisture recycling. J. Hydrol. 1996, 176, 219-225. [CrossRef]

87. Vicente-Serrano, S.M. Spatial and temporal analysis of droughts in the Iberian Peninsula (1910-2000). Hydrol. Sci. J. 2006, 51, 83-97. [CrossRef]

88. Eltahir, E.A.B. A Soil Moisture-Rainfall Feedback Mechanism: 1. Theory and observations. Water Resour. Res. 1998, 34, 765-776. [CrossRef]

89. Zheng, X.; Eltahir, E.A.B. A Soil Moisture-Rainfall Feedback Mechanism: 2. Numerical experiments. Water Resour. Res. 1998, 34, 777-785. [CrossRef]

90. Oloruntadea, A.J.; Mohammad, T.A.; Ghazalib, A.H.; Wayayoka, A. Analysis of meteorological and hydrological droughts in the Niger-South Basin, Nigeria. Glob. Planet. Chang. 2017, 155, 225-233. [CrossRef]

91. Shukla, S.; Wood, A.W. Use of a standardized runoff index for characterizing hydrologic drought. Geophys. Res. Lett. 2008, 35, 1-7. [CrossRef]

92. Mohino, E.; Serge, J.; Bader, J. Sahel rainfall and decadal to mlti-decadal sea surface temperature variability. Clim. Dyn. 2011, 37, 411-440. [CrossRef]

93. Dutra, E.; Di Giuseppe, F.; Wetterhall, F.; Pappenberger, F. Seasonal forecasts of droughts in African basins using the Standardized Precipitation Index. Hydrol. Earth Syst. Sci. 2013, 17, 2359-2373. [CrossRef]

94. Yuan, X.; Wood, E.F.; Chaney, N.W.; Sheffield, J.; Kam, J.; Liang, M.; Guan, K. Probabilistic Seasonal Forecasting of African Drought by Dynamical Models. J. Hydrometeorol. 2013, 14, 1706-1720. [CrossRef]

95. Yu, Y.; Notaro, M.; Wang, F.; Mao, J.; Shi, X.; Wei, Y. Observed positive vegetation-rainfall feedbacks in the Sahel dominated by a moisture recycling mechanism. Nat. Commun. 2017, 8, 1873. [CrossRef]

96. Bosilovich, M.G.; Sud, Y.C.; Schubert, S.D.; Walker, G.K. Numerical simulation of the large-scale North Amer-ican monsoon water sources. J. Geophys. Res. 2003, 108, 8614. [CrossRef]

97. Domínguez, F.; Kumar, P.; Vivoni, E.R. Precipitation Recy-cling Variability and Ecoclimatological Stability-A Study Us-ing NARR Data. Part II: North American Monsoon Region. J. Clim. 2008, 5187-5203. [CrossRef]

98. Lamb, P.J. Case studies of tropical Atlantic surface circulation patterns during recent sub-Saharan weather anomalies: 1967 and 1968. Mon. Weather Rev. 1978, 106, 482-491. [CrossRef]

99. Okonkwo, C.; Demoz, B.; Tesfai, S. Characterization of West African jet streams and their association to ENSO events and rainfall in ERA-Interim 1979-2011. Adv. Meteorol. 2014, 2014, 405617. [CrossRef]

100. Ta, S.; Kouadio, K.Y.; Ali, K.E.; Toualy, E.; Aman, A.; Yoroba, F. West Africa Extreme Rainfall Events and Large-Scale Ocean Surface and Atmospheric Conditions in the Tropical Atlantic. Adv. Meteorol. 2016, 2016, 1940456. [CrossRef]

(C) 2019 by the authors. Licensee MDPI, Basel, Switzerland. This article is an open access article distributed under the terms and conditions of the Creative Commons Attribution (CC BY) license (http:/ / creativecommons.org/licenses/by/4.0/). 